\title{
New developments of insulinomimetic dinuclear vanadyl(IV)-tartrate complexes*
}

\author{
Hiromu Sakurai ${ }^{\ddagger}$, Satoko Funakoshi, and Yusuke Adachi \\ Department of Analytical and Bioinorganic Chemistry, Kyoto Pharmaceutical \\ University, 5 Nakauchi-cho, Misasagi, Yamashina-ku, Kyoto 607-8414, Japan
}

\begin{abstract}
The number of patients suffering from diabetes mellitus (DM) is increasing year by year throughout the world. In 2003, the world population was 6.3 billion, and the number of patients with DM in the adult population (20-79 years old) was 0.194 billion, which corresponded to $5.1 \%$ of all disease incidence in that age range. In 2005, it is forecasted that the world population will increase to 8.0 billion and the ratio of DM to total disease incidence will increase to $6.3 \%$, with a disproportionate number of cases in Southeast Asia, the West Pacific, Central Asia, and North, Central, and South America. To treat Type 1 and Type 2 DM clinically, insulin preparations and synthetic drugs, respectively, have been used. However, these treatments are associated with some problems, such as several times of daily insulin injections following blood glucose monitoring and side effects in the case of the synthetic drugs. Consequently, a new class of therapeutic compounds is anticipated. After many trials, vanadium-containing complexes have been proposed to improve and treat both types of DM by in vivo experiments. We present an overview of insulinomimetic and antidiabetic vanadyl (+4 vanadium, V) complexes, and propose new candidates for dinuclear vanadyl complexes with naturally occurring ligands. The current state of research on the dinuclear vanadyl(IV)-tartrate complexes is described in regard to the physicochemical characteristics, in vitro insulinomimetic and in vivo blood-glucose-lowering effects of the prepared complexes.
\end{abstract}

Keywords: Dinuclear vanadyl-tartrate complex; optically active; racemic; CD spectrum; insulinomimetic activity; blood-glucose-lowering effect; diabetes mellitus.

\section{INTRODUCTION}

Since the 1980s, the normoglycemic effect of vanadium salts in cell systems and diabetic animals has been reported [1-10], together with the mechanisms relevant to both glucose and lipid metabolisms. Thus, the insulinomimetic activity of vanadium salts and complexes is a subject of current research in chemistry, since such compounds have been found not only to mimic the effects of insulin in vitro, but also to induce normoglycemia by improving glucose homeostasis in vivo in Type 1 (insulin-dependent) and Type 2 (non-insulin-dependent) diabetic animals [11-16].

The goal of developing insulinomimetic and antidiabetic compounds is focused on the oral availability, since the compounds are intended for clinical use in place of painful insulin injections [11-13]. Because vanadium salts such as vanadyl $(+4 \mathrm{~V})$ and vanadate $(+5 \mathrm{~V})$ are poorly absorbed by the gastro-

\footnotetext{
*Paper based on a presentation at the $4^{\text {th }}$ International Symposium on Chemistry and Biological Chemistry of Vanadium, Szeged, Hungary, 3-5 September 2004. Other presentations are published in this issue, pp. 1497-1640.

¥Corresponding author: E-mail: sakurai@mb.kyoto-phu.ac.jp
} 
intestinal tracts [17], the finding of orally active insulinomimetic compounds should be directed toward the improvement of bioavailability of such salts by complexation with less toxic low-molecular-weight ligands [17] or capsulation [18]. The history of orally active insulinomimetic vanadium complexes was thus begun in 1990, when mononuclear and dinuclear vanadyl complexes were first proposed [19].

In 1990, we reported that orally administered bis(methylcysteinato)[VO(cysm) $\left.{ }_{2}\right]-$, bis(oxalato) $\left[\mathrm{VO}(\mathrm{ox})_{2}\right]-$, bis(malonato) $\left[\mathrm{VO}(\mathrm{ma})_{2}\right]-$, and bis(salicylaldehyde) $\left[\mathrm{VO}(\mathrm{sal})_{2}\right]$-oxovanadium(IV), as well as bis(L-tartrato)dioxovanadium(IV) $\left[(\mathrm{VO})_{2}(\operatorname{tar})_{2}\right]$ complexes were effective for treating hyperglycemia in streptozotocin (STZ)-induced Type 1 model diabetic rats (STZ rats). The order of the normoglycemic effect in STZ rats was found to be $\mathrm{VO}(\mathrm{ma})_{2}>\mathrm{VO}(\mathrm{cym})_{2}>(\mathrm{VO})_{2}(\operatorname{tar})_{2}>\mathrm{VO}(\mathrm{sal})_{2}>$ $\mathrm{VO}(\mathrm{ox})_{2}$, the action of the complexes being dose-dependent in the vanadium concentration range of $1-10 \mathrm{mg} / \mathrm{kg}$ body wt [19]. In view of the importance of finding more active complexes involving vanadyl (+4) and vanadate (+5) ions, a large number of vanadyl complexes with different coordination structures have been extensively proposed (Fig. 1), with particular emphasis on the efficacy of bis(picolinato) oxovanadium(IV) $\left[\mathrm{VO}(\mathrm{pa})_{2}\right]$ and bis(maltolato)oxovanadium(IV) $\left[\mathrm{VO}(\mathrm{mal})_{2}\right]$ complexes [20-34]. These two complexes have advantages for examining the structure-activity relationship by adding suitable substituents on the picolinate [20-30] and 3-hydroxypyrone [31-34] as leading ligands, respectively. Among them, the complexes bis(6-methylpicolinato)oxovanadium(IV) [VO(6mpa) $\left.{ }_{2}\right]$ and bis(allixinato)oxovanadium(IV) $\left[\mathrm{VO}(\mathrm{alx})_{2}\right]$ are expected to be especially applicable to clinical use.

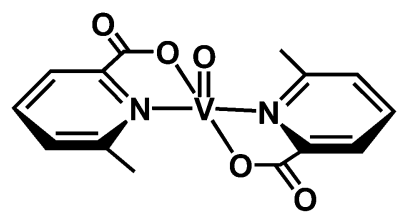

$\mathrm{VO}(6 \mathrm{mpa})_{2}$

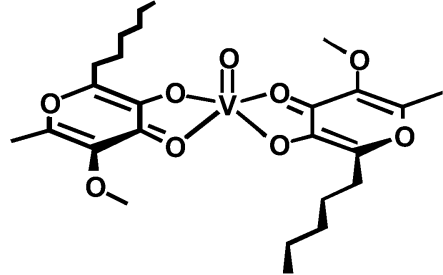

$\mathrm{VO}(\mathrm{alx})_{2}$

In 2001, during the development of insulinomimetic compounds involving vanadyl and vanadate ions, an intriguing study reported that a 6-week oral treatment of vanadyl sulfate $\left[\mathrm{VOSO}_{4}\right]$ at a dose of $150 \mathrm{mg} / \mathrm{d}$ in Type 2 diabetic subjects improved the glycemic state by reducing basal glucose production and enhancing muscle insulin sensitivity [35]. These results not only provided the basis for the treatment of diabetes with vanadium compounds, but also prompted us to find and develop more active insulinomimetic vanadyl complexes.

Following the finding in 1990 that a dinuclear vanadyl complex, $(\mathrm{VO})_{2}(\operatorname{tar})_{2}$, also has a normoglycemic effect in STZ rats [19], we continued to examine the nature of the complexes using L-, D-, and racemic ligands. The currently obtained results should prove useful not only for understanding the nature of the new complexes but also for developing potential insulinomimetic vanadyl complexes. 


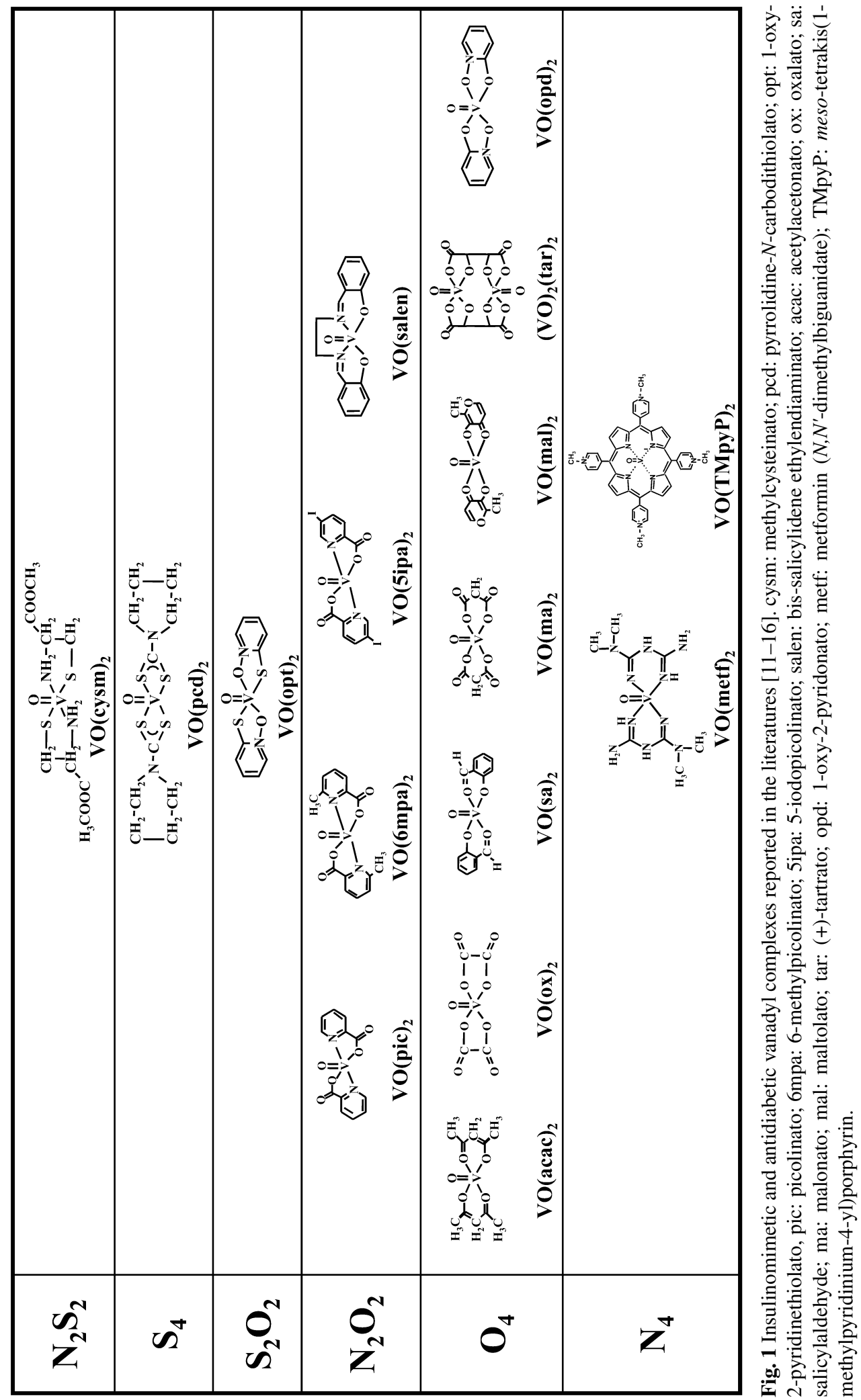

(C) 2005 IUPAC, Pure and Applied Chemistry 77, 1629-1640 


\section{PREPARATION AND CHARACTERIZATION OF DINUCLEAR VANADYL(IV)-TARTRATE COMPLEXES}

When we prepared dinuclear bis(L-tartrato)dioxovanadium(IV) and examined the hypoglycemic effect in STZ rats following single oral administration in 1990 [19], the complex induced a normoglycemic effect in a dose-dependent manner, similar to the effect of $\mathrm{VO}(\mathrm{cysm})_{2}$. These results prompted us to look at important features on the complexes involving the dinuclear structure and the chirality of vanadyl complexes. In fact, these two problems have received little attention since 1990. Because three types of tartaric acids, L-, D- and racemic tartaric acids, are available (Fig. 2), we have prepared several kinds of dinuclear vanadyl complexes using different cations, such as $\mathrm{NH}_{4}{ }^{+}, \mathrm{Na}^{+}$, and $\mathrm{K}^{+}$. In addition, a dinuclear bis(citrato)dioxovanadium(IV) $\left[(\mathrm{VO})_{2}(\mathrm{cit})_{2}\right]$ complex was prepared for comparison. The physicochemical properties of the prepared complexes are summarized in Table 1.<smiles>O=C(O)C(O)C(O)C(=O)O</smiles>

D-tartaric acid

I-tartaric acid

(-)-tartaric acid

unnatural<smiles>O=C(O)C(O)C(O)C(=O)O</smiles>

DL-tartaric acid dl-tartaric acid

$( \pm)$-tartaric acid

racemic 0

2.96, 4.24

Solubility in $\mathrm{H}_{2} \mathrm{O} \quad 1 \mathrm{~g} / 0.75 \mathrm{~mL} \mathrm{H}_{2} \mathrm{O} \quad$ less soluble than L-tart $\quad 1 \mathrm{~g} / 100 \mathrm{~mL} \mathrm{H}_{2} \mathrm{O}$<smiles>O=C(O)C(O)C(O)C(=O)O</smiles>

\section{L-tartaric acid \\ $d$-tartaric acid \\ $(+)$-tartaric acid \\ natural}

$+12.0\left(\mathrm{c}=\mathbf{2 0}\right.$ in $\left.\mathrm{H}_{2} \mathrm{O}\right)$

2.98, 4.34

Solubility in $\mathrm{H}_{2} \mathrm{O} \quad 1 \mathrm{~g} / 0.75 \mathrm{~mL} \mathrm{H}_{2} \mathrm{O} \quad$ less soluble than L-tart $\quad 1 \mathrm{~g} / 100 \mathrm{~mL} \mathrm{H}_{2} \mathrm{O}$

Fig. 2 Structures and physicochemical properties of tartaric acids.

These properties corresponded well with those of the previously reported $\mathrm{Na}_{4}(\mathrm{VO})_{2}(\mathrm{D}-\mathrm{tar})(\mathrm{L}-\mathrm{tar})$ $[36,37]$ and $\mathrm{K}_{4}(\mathrm{VO})_{2}(\mathrm{cit})_{2}[38,39]$ complexes. Although speciation study on vanadyl complexes of tartaric acids and citric acid has previously been reported using $\mathrm{pH}$-potentiometry and spectroscopic methods such as electron spin resonance (ESR) and electronic absorption [40], circular dichroism (CD) spectral method is more sensitive than these methods in characterizing the complexes with chiral ligands. 


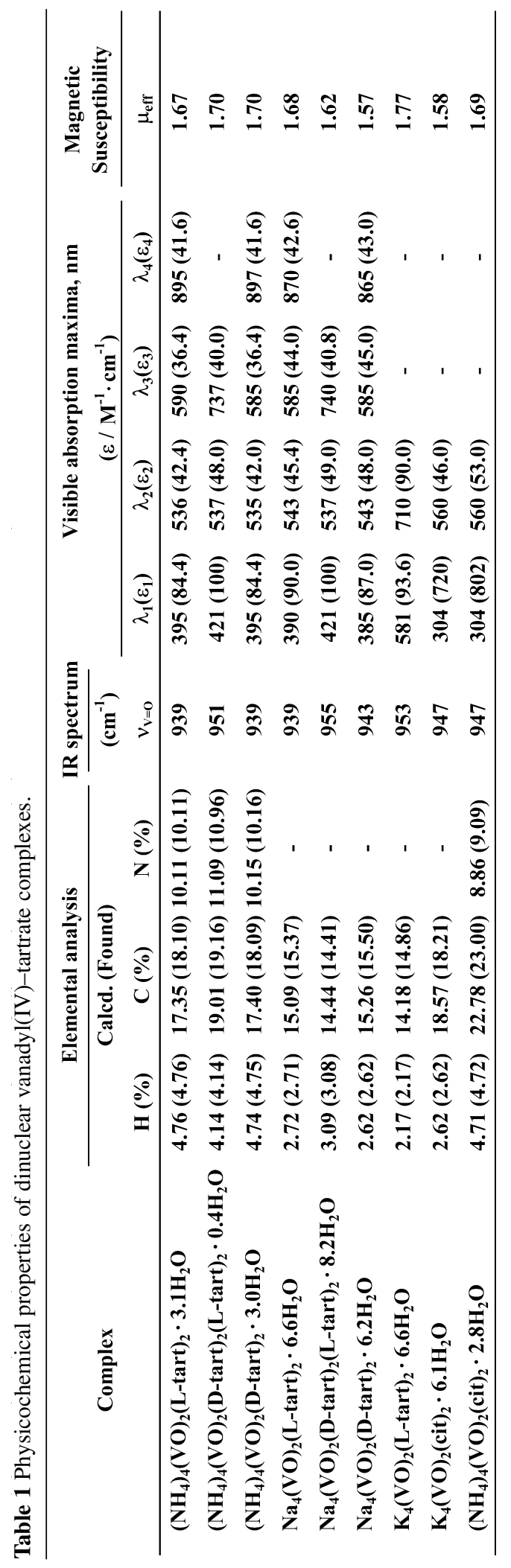

(C) 2005 IUPAC, Pure and Applied Chemistry 77, 1629-1640 
In CD spectral measurement of $\left(\mathrm{NH}_{4}\right)_{4}(\mathrm{VO})_{2}(\operatorname{tar})_{2}$ complexes in aqueous solution, well-separated and symmetrical spectra were obtained in both complexes with optically active L- and D-tartaric acids, while in the racemic complex essentially no CD spectrum was observed, as expected (Fig. 3). Similar CD spectra were obtained in other complexes with different cations.

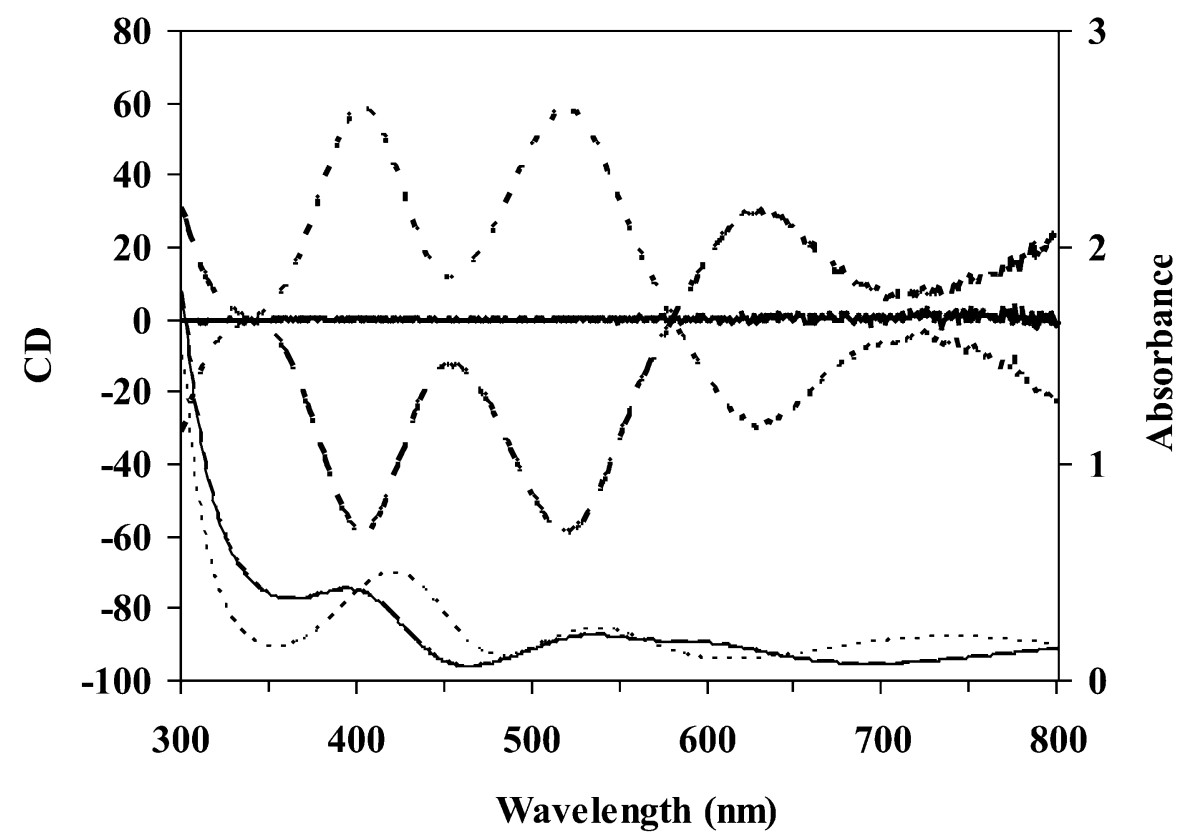

Fig. $3 \mathrm{CD}$ and visible absorption spectra of $\left[\left(\mathrm{NH}_{4}\right)_{4}(\mathrm{VO})_{2}(\operatorname{tar})_{2}\right]$. CD spectra: $\cdots(\text { (L-tar })_{2}$, - (D-tar) $(\mathrm{L}-\operatorname{tar})$, --- $(\mathrm{D}-\operatorname{tar})_{2}$ : Vis spectra: $\cdots(\text { (L-tar })_{2},-(\mathrm{D}-\mathrm{tar})(\mathrm{L}-\mathrm{tar})$, ---- (D-tar $)_{2}$.

Complicated electron paramagnetic resonance (EPR) spectra were observed in $\left(\mathrm{NH}_{4}\right)_{4}(\mathrm{VO})(\operatorname{tar})_{2}$ complexes at both room and liquid nitrogen temperatures (Fig. 4). However, in the racemic $\left(\mathrm{NH}_{4}\right)_{4}(\mathrm{VO})(\mathrm{D}-\mathrm{tar})(\mathrm{L}-\mathrm{tar})$ complex, two separated spectra with an 8-line signal were recorded, suggesting small differences in the $\mathrm{V}-\mathrm{V}$ bond distance in the chiral and racemic complexes. On the $\mathrm{Na}_{4}(\mathrm{VO})_{2}(\mathrm{D}-\mathrm{tar})(\mathrm{L}-\mathrm{tar})[36,37]$ and $\mathrm{K}_{4}(\mathrm{VO})_{2}(\mathrm{cit})_{2}[38,39]$ complexes, X-ray crystallographic structures have already been analyzed. The local structure and the $\mathrm{V}-\mathrm{V}$ bond distance may reflect differences in the EPR spectra. A detailed study of this matter will be needed in the future. 


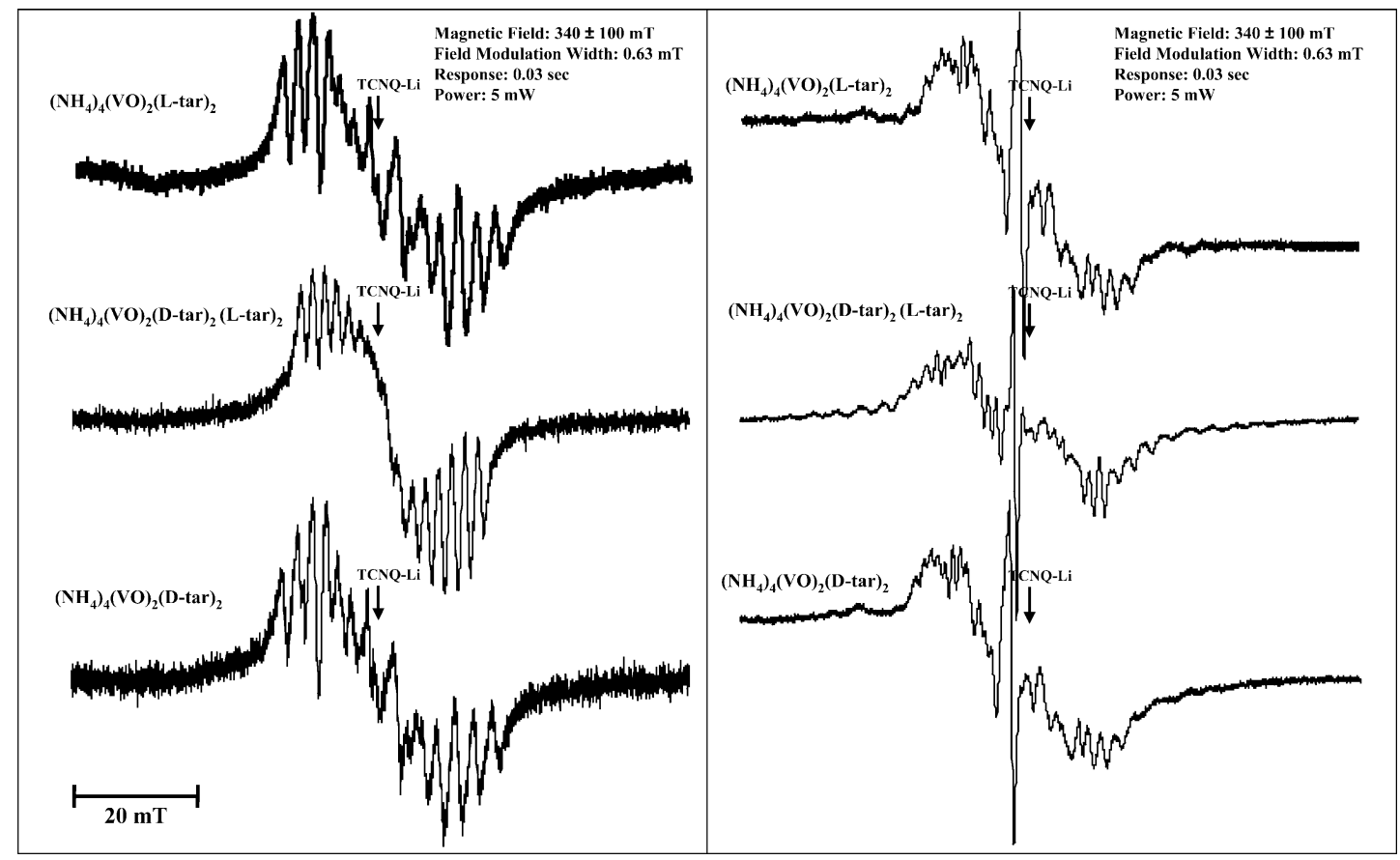

Room Temperature

(RT)
Liquid Nitrogen Temperature

(LNT)

Fig. 4 ESR spectra of $\left[\left(\mathrm{NH}_{4}\right)_{4}(\mathrm{VO})_{2}(\operatorname{tar})_{2}\right]$.

\section{INSULINOMIMETIC EVALUATION OF THE DINUCLEAR VANADYL(IV)-TARTRATE COMPLEXES IN ISOLATED RAT ADIPOCYTES}

Although the molecular basis of the action of vanadium has not yet been fully elucidated, there is evidence that the insulin receptor is activated though the possibilities exist for inhibition of protein tyrosine phosphatase (PTPase), which relates to the activation of cytosolic nonreceptor tyrosine kinase, direct phosphorylation of insulin receptor substrate 1 (IRS-1), and activation of phosphatitylinositol 3 kinase (PI-3K), leading to glucose transporter 4 (GLUT4) translocation [41], as well as the activation of phosphodiesterase [13-15]. As expected, $\mathrm{VOSO}_{4}$ showed insulinomimetic activity with regard to both incorporation of glucose in the rat adipocytes $[6,42]$ as well as inhibition of the free fatty acid (FFA) release from the adipocytes [43] (Fig. 5). Insulin has only one action site, insulin receptor. However, vanadyl ion has multiaction sites in the adipocytes [13-15], similar to the case of zinc(II) ion [44]. We therefore named its mechanism of action an ensemble mechanism. The FFA release is examined with a simple determination kit, which is convenient to test whether or not vanadium ions and the complexes have insulinomimetic activity [13-15,43]. In fact, we have found many types of insulinomimetic vanadyl complexes using this method [13-15], some of which have been proposed for development as antidiabetic complexes with a normoglycemic effect. 


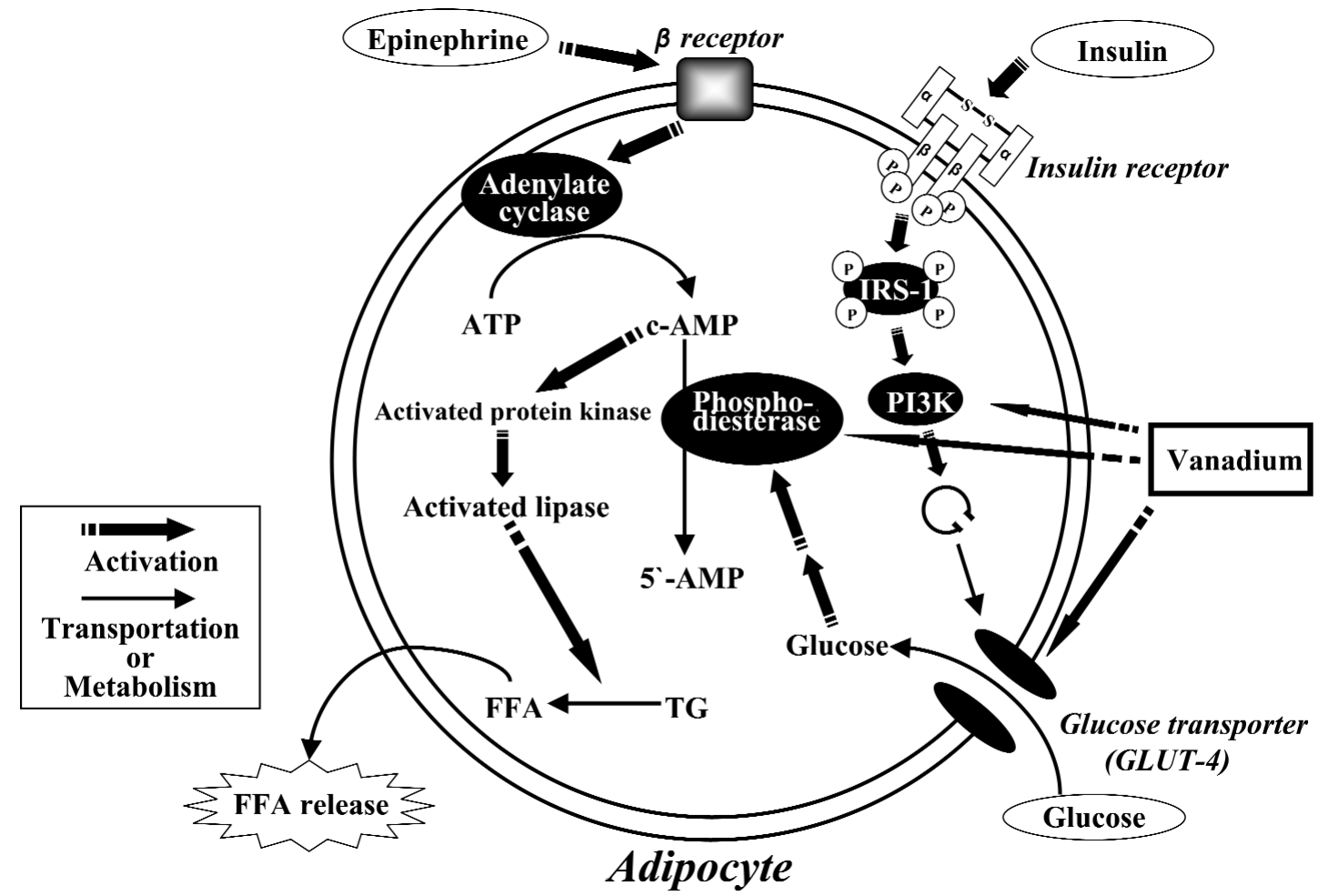

Fig. 5 Possible mechanism for insulinomimetic action of vanadium in isolated rat adipocyte [13-15]. FFA: free fatty acid; IRS: insulin receptor substrate; PI3-K: phosphatidyl inositol 3 kinase; TG: triglyceride.

The dinuclear vanadyl complexes examined exhibited concentration-dependent inhibitory effects on FFA release from the isolated rat adipocytes treated with epinephrine (adrenaline). For each complex, we calculated the $\mathrm{IC}_{50}$ value, which was defined as the concentration necessary to inhibit $50 \%$ of the epinephrine-induced FFA release. As shown in Table $2, \mathrm{Na}_{4}(\mathrm{VO})_{2}(\mathrm{~L} \text {-tar })_{2}$ with naturally occurring ligand L-tartaric acid and racemic $\mathrm{Na}_{4}(\mathrm{VO})_{2}(\mathrm{D}$-tar)(L-tar) exhibited the highest in vitro insulinomimetic activity, followed by ammonium complexes with $(\mathrm{VO})_{2}(\operatorname{tar})_{2}$, without significant differences in the chirality of the complexes. The coordination geometry of both complexes is approximately square-pyramidal, with the $\mathrm{V}-\mathrm{V}$ distance $(4.08 \AA$ ) for the racemic complex being somewhat shorter than that for the $\mathrm{Na}_{4}(\mathrm{VO})_{2}(\mathrm{~L}-\mathrm{tar})_{2}(4.35 \AA)$ [37]. Interestingly, $(\mathrm{VO})_{2}(\mathrm{cit})_{2}$ exhibited less activity than the positive control, $\mathrm{VOSO}_{4}$. The X-ray crystallographic structure of the $\mathrm{Na}_{4}(\mathrm{VO})_{2}(\mathrm{cit})_{2}$ complex was revealed in 1998 [38]: the carboxylate oxygen at the $2^{\text {nd }}$ position of the ligand coordinates simultaneously to 2 vanadium ions, such that 2 vanadyl ions achieve an octahedral coordination geometry with a V-V distance of $3.301 \AA$ [39]. Such differences in the coordination structure as well as the V-V distance between $(\mathrm{VO})_{2}(\operatorname{tar})_{2}$ and $(\mathrm{VO})_{2}(\mathrm{cit})_{2}$ complexes suggests a difference in the stability constants of the complexes in solution, as indicated by speciation study, in which the stability constant $(\log \beta=10.73$ : $(\mathrm{VO})_{2} \mathrm{~A}_{2} \mathrm{H}_{-2}$ ) for $(\mathrm{VO})_{2}(\mathrm{cit})_{2}$ complex with octahedral coordination geometry is higher than that $\left(\log \beta=6.24\right.$ : $\left.(\mathrm{VO})_{2} \mathrm{~A}_{2} \mathrm{H}_{-2}\right)$ for $(\mathrm{VO})_{2}(\mathrm{~L}-\mathrm{tar})_{2}$ complex with square-pyramidal coordination geometry [40]. 
Table 2 Insulinomimetic activity of vanadyl compounds in terms of $50 \%$ inbitory concentration of compounds for FFA release from the adipocytes in the presence of epinephrine.

\begin{tabular}{|c|c|}
\hline Compound & $\mathrm{IC}_{50} / \mathrm{mM}( \pm$ S.D $)$ \\
\hline $\mathrm{VOSO}_{4}$ & $1.00 \pm 0.09$ \\
\hline$\left(\mathrm{NH}_{4}\right)_{4}(\mathrm{VO})_{2}(\mathrm{~L}-\mathrm{tar})_{2}$ & $0.83 \pm 0.15$ \\
\hline$\left(\mathrm{NH}_{4}\right)_{4}(\mathrm{VO})_{2}(\mathrm{D}-\mathrm{tar})(\mathrm{L}-\mathrm{tar})$ & $0.84 \pm 0.22$ \\
\hline$\left(\mathrm{NH}_{4}\right)_{4}(\mathrm{VO})_{2}(\mathrm{D}-\mathrm{tar})_{2}$ & $0.87 \pm 0.27$ \\
\hline $\mathrm{Na}_{4}(\mathrm{VO})_{2}(\mathrm{~L}-\mathrm{tar})_{2}$ & $0.74 \pm 0.10$ \\
\hline $\mathrm{Na}_{4}(\mathrm{VO})_{2}(\mathrm{D}-\mathrm{tar})(\mathrm{L}-\mathrm{tar})$ & $0.69 \pm 0.32$ \\
\hline $\mathrm{Na}_{4}(\mathrm{VO})_{2}(\mathrm{D}-\mathrm{tar})_{2}$ & $0.95 \pm 0.30$ \\
\hline $\mathrm{K}_{4}(\mathrm{VO})_{2}(\mathrm{cit})_{2}$ & $1.11 \pm 0.17$ \\
\hline
\end{tabular}

\section{NORMOGLYCEMIC EFFECTS OF DINUCLEAR VANADYL(IV)-TARTRATE COMPLEXES}

Based on the results of in vitro insulinomimetic evaluation of the complexes, we examined the $\mathrm{Na}_{4}(\mathrm{VO})_{2}(\operatorname{tar})_{2}$ complexes in vivo using STZ mice. When three complexes with different chiralities were given to STZ mice following single oral administration at a dose of $20 \mathrm{mg}$ vanadium $/ \mathrm{kg}$ body wt, the hyperglycemia of the mice was improved to almost the normoglycemic state after $5 \sim 25 \mathrm{~h}$ by both $\mathrm{Na}_{4}(\mathrm{VO})_{4}(\mathrm{~L}-\mathrm{tar})_{2}$ and $\mathrm{Na}_{4}(\mathrm{VO})_{4}(\mathrm{D}-\mathrm{tar})$ (L-tar) (Fig. 6). Since the dates for the blood glucose levels of STZ mice given $\mathrm{Na}_{4}(\mathrm{VO})_{2}$ (L-tar) $)_{2}$ were less dispersed than those of the racemic complex, we examined the former complex following daily administration for 10 days.

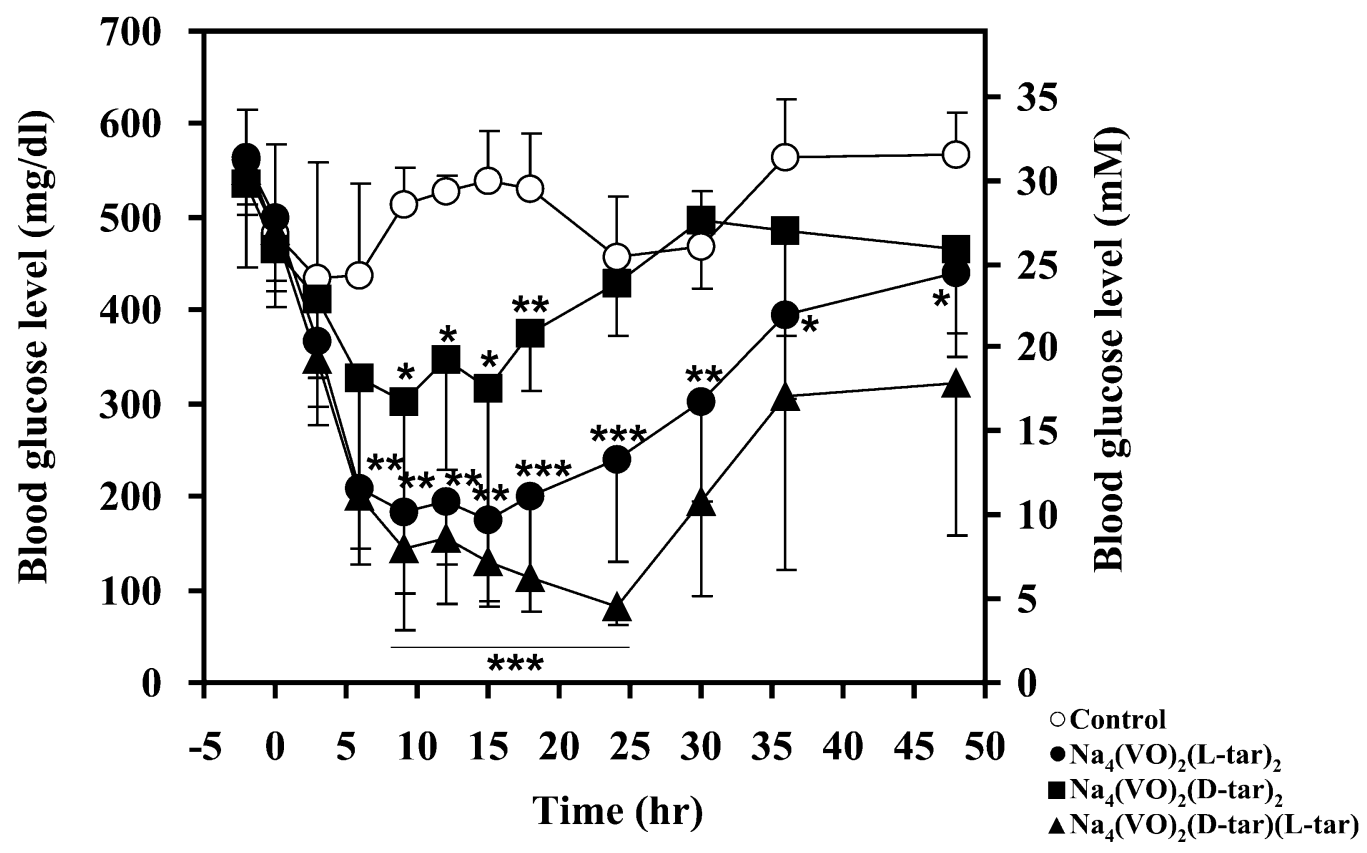

Fig. 6 Changes of blood glucose levels in STZ mice following single oral administration of $\mathrm{Na}_{4}(\mathrm{VO})_{2}(\operatorname{tar})_{2}$ at a dose of $20 \mathrm{mg} \mathrm{V} / \mathrm{kg}$ body weight $(n=5)$. ***Significance at $P<0.05$ vs. control; **Significance at $P<0.01$ vs. control; *Significance at $P<0.001$ vs. control 
STZ mice received daily oral administrations of $\mathrm{Na}_{4}(\mathrm{VO})_{2}(\mathrm{~L}-\mathrm{tar})_{2}$ complex at a dose of $20 \mathrm{mg}$ vanadium $/ \mathrm{kg}$ body wt for the first 3 days, and then the doses were changed to within the range of 0-20 mg vanadium $/ \mathrm{kg}$ body wt depending on the blood glucose levels of the animals. For the combined group of all animals tested, hypoglycemic effects were observed on the $4^{\text {th }}$ day after the complex administration; however, the complex effects were reduced gradually after the $4^{\text {th }}$ day (Fig. 7A). Then we separated the animals into two groups, a high-response and a low-response group. As seen in Fig. 7B, in the high-response group the normoglycemic effect of the complexes was maintained as long as the daily complex administration was continued. In the low-response group, the normoglycemia was gradually reduced despite the continued administration of the complex. Such occurrence of tolerance by vanadium complexes has been reported previously [45]. The unexpected occurrence of tolerance of the complex for the STZ mice observed here underscores the potentially important roles of the complexes in treating Type 1 diabetic animals. In the present study, we used STZ mice with relatively severe Type 1 diabetes as indicated by high blood glucose levels as approximately $570 \mathrm{mg} / \mathrm{dl}(33 \mathrm{mM})$. In such conditions, $\beta$-cell functions are considered to be fully impaired [41]. In spite of high impairment of $\beta$-cell functions in STZ mice, $\mathrm{Na}_{4}(\mathrm{VO})_{2}(\mathrm{~L} \text {-tar })_{2}$ exhibited once normoglycemic effects in all animals after the $4^{\text {th }}$ day of the complex administration (Fig. 7). The results strongly indicate that $\mathrm{Na}_{4}(\mathrm{VO})_{2}(\mathrm{~L}-\mathrm{tar})_{2}$ can be used as an insulinomimetic agent in place of insulin injection. Therefore, the complexes should be examined in relation to unusual or unexpected inhibition of some enzymes or activation of specific excretory pathways of the complex in cells and tissues.

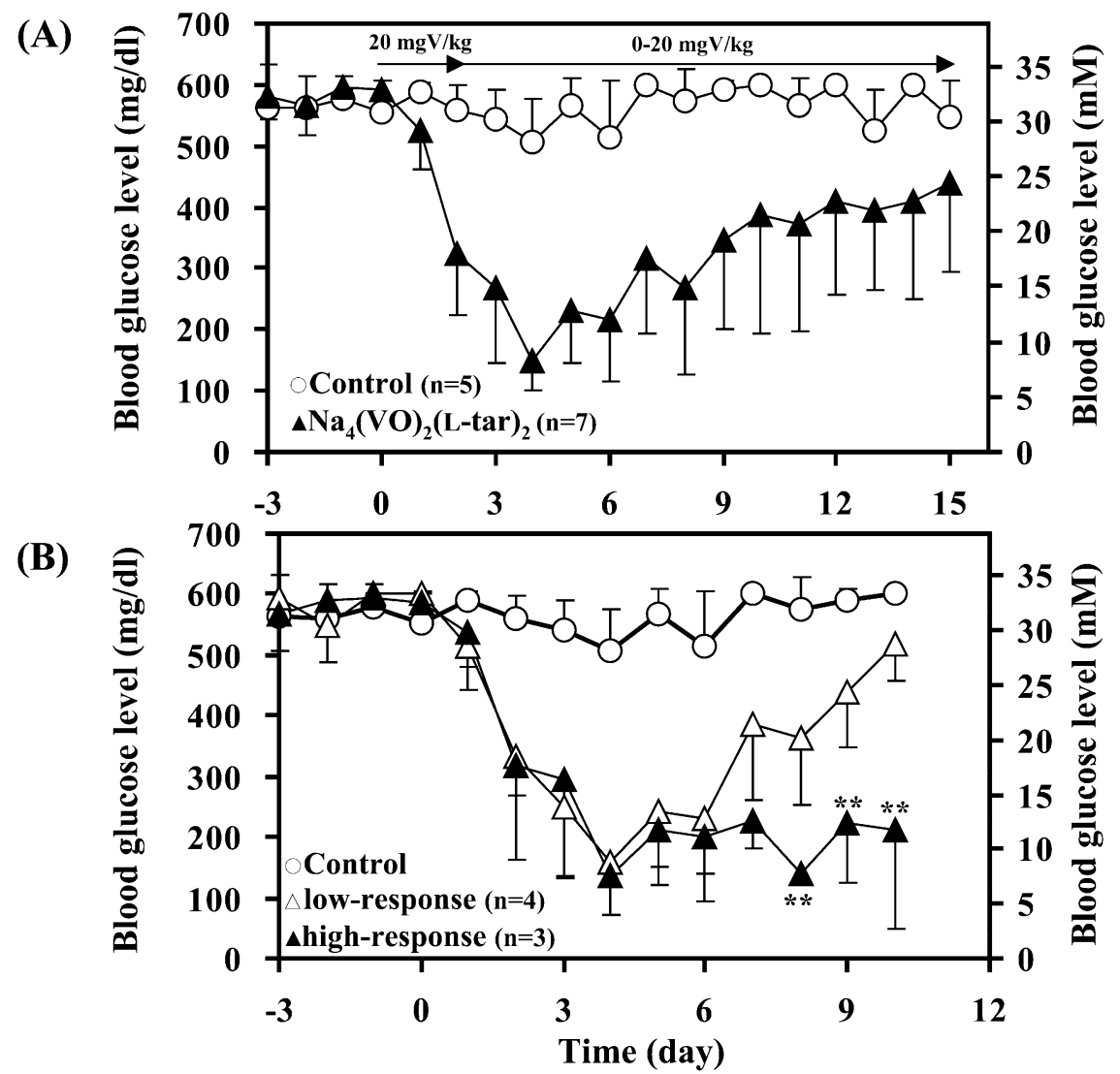

Fig. 7 Changes of blood glucose levels in STZ mice treated with daily oral administrations of $\mathrm{Na}_{4}(\mathrm{VO})_{2}(\mathrm{~L}-\mathrm{tar})_{2}$ (A) Whole data; (B) separation of the data (A) into low- and high-response groups. **Significance at $P<0.05$ vs. non-response. 


\section{SUMMARY}

This article provides a short overview of recent research on the development of insulinomimetic and antidiabetic vanadyl complexes as well as the current stage of our study on new candidates for dinuclear vanadyl(IV)-tartrate complexes with optically active chiral ligands and a racemic ligand. The preparation and physicochemical characteristics and the in vitro insulinomimetic and in vivo antidiabetic effects of several dinuclear complexes are described. With respect to the in vitro and in vivo evaluations of the complexes, sodium salt of the dinuclear vanadyl(IV)-tartrate complex with naturally occurring L-tartaric acid as the ligand was recommended for treating the diabetic animals, although the occurrence of tolerance in the animals was observed. The dimeric structure of vanadyl complexes is also of considerable biological relevance. Dinuclear vanadyl(IV)-tartrate complexes exhibited in vitro insulinomimetic activity, while similar dinuclear vanadyl(IV)-citrate complexes exhibited less activity than $\mathrm{VOSO}_{4}$. These results might be of interest for future study.

Together, the results suggest the importance of not only the structure of these complexes in solution, but also the interaction between the complexes and many types of biomolecules with low and high molecular weights. These mechanistic studies and experimental demonstrations of the chemical, biochemical, and physiological features of the proposed new dinuclear vanadyl(IV)-tartrate complexes should be supplemented with studies assessing the impact of the proposed complexes.

\section{ACKNOWLEDGMENTS}

This study was supported by grants from the Ministry of Education, Science, Sports, and Culture of the Japanese Government [Grants-in-Aid for Scientific Research (B), Scientific Research on Priority Areas, and Specially Promoted Research].

\section{REFERENCES}

1. Y. Shechter and S. J. D. Karlish. Nature 284, 556-558 (1980).

2. J. Meyerovitch, Z. Farfel, J. Sack, Y. Shechter. J. Biol. Chem. 262, 6658-6662 (1987).

3. C. E. Heyliger, A. G. Tahiliani, J. H. McNeill. Science 227, 1474-1477 (1985).

4. S. M. Brichard, W. Okitolonda, J. C. Henquin. Endocrinology 123, 2048-2053 (1988).

5. I. G. Fantus, S. Kadota, G. Deragon, B. Foster, B. I. Posner. Biochemistry 28, 8864-8871 (1989).

6. H. Sakurai, K. Tsuchiya, M. Nakatsuka, M. Sofue, J. Kawada. J. Endocrinol. 126, 451-459 (1990).

7. S. M. Brichard, C. J. Bailey, J. C. Henquin. Diabetes 39, 1326-1332 (1990).

8. R. A. Pederson, S. Ramanadham, A. M. J. Buchan, J. McNeill. Diabetes 38, 1390-1395 (1989).

9. J. H. McNeill, V. G. Yuen, H. R. Hoveyda, C. Orvig. J. Med. Chem. 35, 1489-1491 (1992).

10. A. B. Goldfine, D. C. Simonson, F. Folli, M. Patti, C. R. Kahn. J. Clin. Endocrinol. Metab. 80, 3311-3320 (1995).

11. K. H. Thompson, J. H. McNeill, C. Orvig. Chem. Rev. 99, 2561-2571 (1999).

12. K. H. Thompson and C. Orvig. J. Chem. Soc., Dalton Trans. 2885-2892 (2000).

13. H. Sakurai. Chem. Rec. 2, 237-248 (2002).

14. H. Sakurai, Y. Kojima, Y. Yoshikawa, K. Kawabe, H. Yasui. Coord. Chem. Rev. 226, 187-198 (2002).

15. H. Sakurai, H. Yasui, Y. Adachi. Expert Opin. Investig. Drug 12, 1189-1203 (2003).

16. D. C. Crans, J. J. Smee, E. Gaidamauskas, L. Yang. Chem. Rev. 104, 849-902 (2004).

17. J. Fugono, H. Yasui, H. Sakurai. J. Pharm. Pharmacol. 53, 1247-1255 (2001).

18. J. Fugono, H. Yasui, H. Sakurai. J. Pharm. Pharmacol. 54, 611-615 (2002).

19. H. Sakurai, K. Tsuchiya, M. Nukatsuka, J. Kawada, S. Ishikawa, H. Yoshida. J. Clin. Biochem. Nutr. 8, 193-200 (1990). 
20. H. Sakurai, K. Fujii, H. Watanabe, H. Tamura. Biochem. Biophys. Res. Commun. 214, 1095-1101 (1995).

21. S. Fujimoto, K. Fujii, H. Yasui, R. Matsushita, J. Takada, H. Sakurai. J. Clin. Biochem. Nutr. 23, 113-129 (1997).

22. Y. Fujisawa and H. Sakurai. Chem. Pharm. Bull. 47, 1668-1670 (1999).

23. H. Yasui, K. Takechi, H. Sakurai. J. Inorg. Biochem. 78, 185-196 (2000).

24. H. Sakurai, A. Tamura, T. Takino, K. Ozutsumi, K. Kawabe, Y. Kojima. Inorg. Rec. Mechan. 2, 69-77 (2000).

25. T. Takino, H. Yasui, A. Yoshitake, Y. Hamajima, R. Matsushita, J. Takada, H. Sakurai. J. Biol. Inorg. Chem. 6, 133-142 (2001).

26. T. Sasagawa, Y. Yoshikawa, K. Kawabe, H. Sakurai, Y. Kojima. J. Inorg. Biochem. 88, 108-112 (2002).

27. H. Yasui, A, Tamura, T. Takino, H. Sakurai. J. Inorg. Biochem. 91, 327-338 (2002).

28. S. Yano, M. Nakai, F. Sekiguchi, M. Obata, M. Kato, M. Shiro, I. Kinoshita, M. Mikuriya, H. Sakurai, C. Orvig. Chem. Lett. $916-917$ (2002).

29. J. Gätjens, B. Meier, T. Kiss, E. M. Nagy, P. Buglyo, H. Sakurai, K. Kawabe, D. Rehder. Chem. Eur. J. 9, 4924-4935 (2003).

30. M. Nakai, M. Obata, F. Sekiguchi, M. Kato, M. Shiro, A. Ichimura, I. Kinoshita, M. Mikuriaya, T. Inohara, K. Kawabe, H. Sakurai, C. Orvig, S. Yano. J. Inorg. Biochem. 98, 105-112 (2004).

31. J. H. McNeill, V. G. Yuen, H. R. Hoveyda, C. Orvig. J. Med. Chem. 35, 1489-1491 (1992).

32. B. Song, N. Aebischer, C. Orvig. Inorg. Chem. 41, 1357-1364 (2002).

33. K. H. Thompson, B. D. Liboiron, Y. Sun, K. D. D. Bellman, I. A. Setyawati, B. O. Patrick, V. Karunaratne, G. Rawji, J. Wheeler, K. Sutton, S. Bhanot, C. Cassidy, J. H. McNeill, V. G. Yuen, C. Orvig. J. Biol. Inorg. Chem. 8, 66-74 (2003).

34. Y. Adachi, J. Yoshida, Y. Kodera, A. Katoh, H. Sakurai. The $4^{\text {th }}$ Int. Symp. Chem. Biol. Chem. Vanadium. Abstract P1, Szeged, Hungary (2004).

35. K. Cusi, S. Cukier, R. A. Defronzo, M. Torres, F. M. Puchulu, P. J. C. Redondo. J. Clin. Endocrinol. Metab. 86, 1410-1417 (2001).

36. R. E. Tapscott, R. L. Belford, I. C. Paul. Inorg. Chem. 7, 356-364 (1968).

37. R. E. Tapscott and R. L. Belford. Inorg. Chem. 6, 735-743 (1967).

38. M. Velayutham, B. Varghese, S. Subramanian. Inorg. Chem. 37, 1336-1340 (1998).

39. M. Tsaramyrsi, M. Kaliva, A. Salifoglou, C. P. Raptopoulou, A. Terzis, V. Tangoulis, J. Giapintzakis. Inorg. Chem. 40, 5772-5779 (2001).

40. T. Kiss, P. Buglyo, D. Sanna, G. Micera, P. Decock, D. Dewaele. Inorg. Chim. Acta 239, 145-153 (1995).

41. E. Shafrir, S. Spielman, I. Nachliel, M. Khamaisi, H. Bar-On, E. Ziv. Diabetes Metab. Res. Rev. 17, 55-66 (2001).

42. Y. Adachi and H. Sakurai. Chem. Pharm. Bull. 52, 428-433 (2004).

43. M. Nakai, H. Watanabe, C. Fujiwara, H. Kakegawa, T. Satoh, J. Takada, R. Matsushita, H. Sakurai. Biol. Pharm. Bull. 18, 719-725 (1995).

44. Y. Yoshikawa, E. Ueda, Y. Kojima, H. Sakurai. Life Sci. 75, 741-751 (2004).

45. M. C. Cam, R. W. Brownsey, J. H. McNeill. Can. J. Physiol. Pharmacol. 78, 829-847 (2000). 